\title{
MULTIMOORA-FG: A Multi-Objective Decision Making Method for Linguistic Reasoning with an Application to Personnel Selection
}

\author{
Alvydas BALEŽENTIS ${ }^{1}$, Tomas BALEŽENTIS ${ }^{2}$, \\ Willem K.M. BRAUERS ${ }^{3}$ \\ ${ }^{1}$ Mykolas Romeris University, Valakupiu 5, LT-10101 Vilnius, Lithuania \\ ${ }^{2}$ Lithuanian Institute of Agrarian Economics, V. Kudirkos 18, LT-03105 Vilnius, Lithuania \\ ${ }^{3}$ University of Antwerp, Birontlaan, 97, B2600 Berchem-Antwerpen, Belgium \\ e-mail:a.balezentis@gmail.com,tomas@laei.lt,willem.brauers@ua.ac.be
}

Received: May 2011; accepted: September 2011

\begin{abstract}
This paper aims to extend fuzzy MULTIMOORA with linguistic reasoning and group decision-making (MULTIMOORA-FG). The new method consists of the three parts, namely the fuzzy Ratio System, the fuzzy Utopian Reference Point, and the fuzzy Full Multiplicative Form offering a robust comparison of alternatives against multiple objectives. In addition, MULTIMOORA-FG is designed to deal with triangular fuzzy numbers which, in turn, can resemble linguistic variables. MULTIMOORA-FG is a proper instrument for linguistic reasoning under fuzzy environment. In our study an application of personnel selection illustrates the group decisionmaking procedure according to MULTIMOORA-FG. Given the uncertainties peculiar of personnel selection, the application of multi-objective decision making (MODM) is required in this area. Fuzzy MULTIMOORA enables to aggregate subjective assessments of the decision-makers and thus offer an opportunity to perform a more robust personnel selection. The committee decided to consider eight qualitative characteristics expressed in linguistic variables. A numerical example exhibited possibilities for improvement of human resources management or any other business decision-making by applying MULTIMOORA-FG.
\end{abstract}

Keywords: personnel selection, personnel management, employment decisions, human resources management, multi-objective optimization, MULTIMOORA, MULTIMOORA-FG, fuzzy number, linguistic reasoning.

\section{Introduction}

Multi-objective decision-making methods (MODM) methods can deal with a selection process: by finding an optimal solution from a set of available alternatives according to a set of objectives. Sometimes none of the alternatives satisfies all the objectives. Then a satisfactory decision is made instead of an optimal one. Roy (1996) presented the following pattern of MODM problems: (1) $\alpha$ choosing problem - choosing the best alternative; (2) $\beta$ sorting problem - classifying alternatives into relatively homogenous groups; (3) $\gamma$ ranking problem - ranking alternatives from best to worst; (4) $\delta$ describing problem - describing alternatives in terms of their peculiarities and features. Belton 
and Stewart (2002) defined the three broad categories of MODM methods (Loken, 2007; Zavadskas and Turskis, 2011): (1) value measurement models; (2) goal, aspiration, and reference level models; (3) outranking models (the French school). In this study we will extend and apply the MOORA and MULTIMOORA methods.

The Multi-Objective Optimization by Ratio Analysis (MOORA) was introduced by Brauers and Zavadskas (2006). Subsequently, these authors further developed the method (Brauers and Zavadskas, 2010a) thus presenting the MULTIMOORA (MOORA plus the full multiplicative form). Numerous examples of application of MULTIMOORA are present. The MULTIMOORA was applied as well as in a manufacturing and engineering environment (Kracka et al., 2010; Chakraborty, 2011; Brauers et al., 2008a, 2008b; Kalibatas and Turskis, 2008), as in regional development studies (Brauers and Zavadskas, 2010b, 2011b; Brauers and Ginevičius, 2009, 2010; Brauers et al., 2007). The theory of dominance (Brauers and Zavadskas, 2011a) enables to summarize the ranks obtained from different parts of MULTIMOORA. Moreover, MULTIMOORA has been updated with fuzzy number theory (Brauers et al., 2011).

In this study a personnel selection case will be used as an assumed example. Personnel selection is an important part of human resources management in an enterprise. It tries to find the best candidate for a well-defined vacancy also with determination of the input quality of the personnel (Dursun and Karsak, 2010). The ongoing processes of globalization as well as the increasing competition require improving the personnel selection. However, many enterprises are not ready to make available the vast amount of funds for personnel selection. Hence, it is important to develop new decision-making techniques available for enterprises asking for various technological, financial, or intellectual capacities. Consequently, more and more scientists have analyzed the practice of personnel recruitment (Zavadskas et al., 2008). Indeed, the complexity of personnel selection requires the application of MODM for robust recruitment. Consequently, MODM methods were applied in many studies focused on personnel recruitment (Dursun and Karsak, 2010; Zhang, Liu, 2011; Kelemenis and Askounis, 2010; Kelemenis et al., 2011; Merigo and Gil-Laufente, 2011; Zavadskas et al., 2008). The latter two sources provide comprehensive reviews of studies on personnel selection.

Zadeh (1965), the Founder of fuzzy logic, proposed employing the fuzzy set theory as a modelling tool for complex systems that are hard to define exactly in crisp numbers. Fuzzy logic hence allows coping with vague, imprecise and ambiguous inputs and knowledge (Kahraman, 2008; Kahraman and Kaya, 2010). Linguistic reasoning relying on fuzzy logics was introduced by Zadeh (1975a, 1975b, 1975c) and applied in many studies (Liang, 1999; Chen, 2000; Chou et al., 2008; Torlak et al., 2011; Kaya and Kahraman, 2011).

This paper aims at extending the fuzzy MULTIMOORA for linguistic reasoning under group decision-making. The extended fuzzy MULTIMOORA is applied for solving personnel selection. Therefore the remaining part of the paper is organized in the following way. Section 2 describes the basics of fuzzy number theory, linguistic reasoning, and MULTIMOORA. The following Section 3 presents the extended fuzzy MULTIMOORA for group decision making. Finally, Section 4 sets forward a numerical example of personnel selection. 


\section{Preliminaries}

\subsection{The Fuzzy Set Theory and Triangular Fuzzy Numbers}

Fuzzy sets and fuzzy logic are powerful mathematical tools for modeling uncertain systems. A fuzzy set is an extension of a crisp set. Crisp sets only allow full membership or non-membership, while fuzzy sets allow partial membership. The theoretical fundaments of fuzzy set theory are overviewed by Chen (2000).

In a universe of discourse $X$, a fuzzy subset $\tilde{A}$ of $X$ is defined with a membership function $\mu_{\tilde{A}}(x)$ which maps each element $x \in X$ to a real number in the interval $[0 ; 1]$. The function value of $\mu_{\tilde{A}}(x)$ resembles the grade of membership of $x$ in $\tilde{A}$. The higher the value of $\mu_{\tilde{A}}(x)$, the higher the degree of membership of $x$ in $\tilde{A}$ (Keufmann and Gupta, 1991). Noteworthy, in this study any variable with tilde will denote a fuzzy number.

A fuzzy number $\tilde{A}$ is described as a subset of real number whose membership function $\mu_{\tilde{A}}(x)$ is a continuous mapping from the real line $\Re$ to a closed interval [0;1], which has the following characteristics: (1) $\mu_{\tilde{A}}(x)=0$, for all $x \in(-\infty ; a] \cup[c ; \infty)$; (2) $\mu_{\tilde{A}}(x)$ is strictly increasing in $[a ; b]$ and strictly decreasing in $[d ; c]$; (3) $\mu_{\tilde{A}}(x)=1$, for all $x \in[b ; d]$, where $a, b, d$, and $c$ are real numbers, and $-\infty<a \leqslant b \leqslant d \leqslant c<\infty$. When $b=d$ a fuzzy number $\tilde{A}$ is called a triangular fuzzy number (Fig. 1) represented by a triplet $(a, b, c)$. Triangular fuzzy numbers will therefore be used in this study to characterize the alternatives. The membership function $\mu_{\tilde{A}}(x)$ is thus defined as:

$$
\mu_{\tilde{A}}(x)= \begin{cases}0, & x<a, \\ \frac{x-a}{b-a}, & a \leqslant x \leqslant b, \\ \frac{x-c}{b-c}, & b \leqslant x \leqslant c, \\ 0, & x>c .\end{cases}
$$

In addition, the parameters $a, b$, and $c$ in (1) can be considered as indicating respectively the smallest possible value, the most promising value, and the largest possible value that describe a fuzzy event (Torlak et al., 2011).

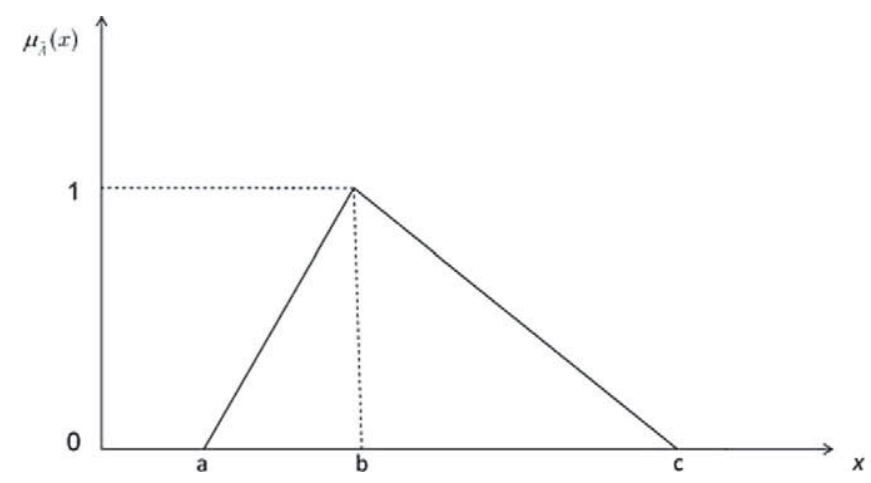

Fig. 1. Membership function of a triangular fuzzy number $\tilde{A}=(a, b, c)$. 
Let $\tilde{A}$ and $\tilde{B}$ be two positive fuzzy numbers (Liang and Ding, 2003). Hence, the main algebraic operations of any two positive fuzzy numbers $\tilde{A}=(a, b, c)$ and $\tilde{B}=(d, e, f)$ can be defined in the following way (Merigo and Casanovas, 2011):

1. Addition $\oplus$ :

$$
\tilde{A} \oplus \tilde{B}=(a, b, c) \oplus(d, e, f)=(a+d, b+e, c+f)
$$

2. Subtraction $\ominus$ :

$$
\tilde{A} \ominus \tilde{B}=(a, b, c) \ominus(d, e, f)=(a-f, b-e, c-d)
$$

3. Multiplication $\otimes$ :

$$
\tilde{A} \otimes \tilde{B}=(a, b, c) \otimes(d, e, f)=(a \times d, b \times e, c \times f) ;
$$

4. Division $\oslash$ :

$$
\tilde{A} \oslash \tilde{B}=(a, b, c) \oslash(d, e, f)=(a / f, b / e, c / d) .
$$

The vertex method will be applied to measure the distance between two fuzzy numbers. Let $\tilde{A}=(a, b, c)$ and $\tilde{B}=(d, e, f)$ be two triangular fuzzy numbers. Then, the vertex method can be applied to measure the distance between these two fuzzy numbers:

$$
d(\tilde{A}, \tilde{B})=\sqrt{\frac{1}{3}\left[(a-d)^{2}+(b-e)^{2}+(c-f)^{2}\right]} .
$$

Fuzzy numbers can be applied in two ways when forming the response matrix of alternatives on objectives. First, fuzzy numbers can represent the values of linguistic variables (Zadeh, 1975a, 1975b, 1975c) when deciding either on the importance of criteria or performing qualitative evaluation of alternatives. For the latter purpose Chen (2000) describes the following fuzzy numbers identifying values of linguistic variables from scale Very poor to Very good: Very poor - $(0,0,1)$; Poor - $(0,1,3)$; Medium poor - $(1,3,5)$; Fair - $(3,5,7)$; Medium good - $(5,7,9)$; Good - (7, 9, 10); Very good - $(9,10,10)$. Second, the fuzzy numbers can represent monetary (quantitative) terms. It can be done either through direct input of certain fuzzy numbers into the response matrix or by aggregation of raw data (e.g., time series). For example, if there are costs "approximately equal to $\$$ 200 " estimated, the sum can be represented by triangular fuzzy number $(190,200,210)$. Moreover, the fuzzy numbers can embody expected rate of growth. For example, if there is level of unemployment of 5 per cent with expected growth of 10 per cent, a triangular fuzzy number $(5,5.5,6.1)$ can summarize these characteristics. As for time series data, a fuzzy number can represent the dynamics of certain indicator during past $t$ periods:

$$
\left(\min _{p}\left\{a_{p}\right\},\left(\prod_{p=1}^{t} a_{p}\right)^{1 / t}, \max _{p}\left\{a_{p}\right\}\right)
$$


where $a_{p}$ represents the value of certain indicator during period $p(p=1,2, \ldots, t)$.

The results of comparison of alternatives based on fuzzy numbers are also expressed in fuzzy numbers. The fuzzy numbers therefore need to be converted into crisp ones in order to identify the most promising alternative. There are four defuzzification methods commonly employed: (i) the centered method (or centre of area - COA); (ii) the Meanof-maximum (MOM); (iii) the $\alpha$-cut method; and (iv) the signed distance method (Zhao and Govind, 1991; Yao and $\mathrm{Wu}, 2000$ ). In this study the COA method will be applied to obtain the Best Non-fuzzy Performance (BNP) value:

$$
B N P_{\tilde{A}}=\frac{(c-a)+(b-a)}{3}+a,
$$

where $a, b$ and $c$ are respectively the lower, modal, and upper values of fuzzy number $\tilde{A}=(a, b, c)^{1}$ (Triantaphyllou, 2000; Zavadskas and Antucheviciene, 2006, 2007). Moreover, the robustness as well as precision of multicriteria optimization can be improved by applying either intuitionist fuzzy numbers (Zhang and Liu, 2010) or two-tuple linguistic representation (Liu, 2009).

\subsection{The MULTIMOORA Method}

Multi-Objective Optimization by Ratio Analysis (MOORA) was introduced by Brauers and Zavadskas (2006) on the basis of previous research by Brauers (2004). Brauers and Zavadskas (2010a) extended the method and in this way it became more robust as MULTIMOORA (MOORA plus the full multiplicative form). These methods have been applied in numerous studies (Brauers et al., 2007; Brauers and Ginevičius, 2009, 2010; Brauers and Zavadskas, 2009) focused on regional studies, international comparisons and investment management.

MOORA method begins with matrix $x_{i j}$ where its elements $x_{i j}$ denote $i$ th alternative of $j$ th objective $(i=1,2, \ldots, m$ and $j=1,2, \ldots, n)$. MOORA method consists of two parts: the ratio system and the reference point approach. MacCrimmon (1968) defines two stages of weighting, namely normalization and voting on significance of objectives. The issue of weighting is discussed by Brauers and Zavadskas (2010), Zavadskas et al. (2010b), while the problem of normalization is analyzed by Brauers (2007) and Turskis et al. (2009).

The MOORA method includes internal normalization and treats originally all the objectives equally important. In principle all stakeholders interested in the issue only could give more importance to an objective. Therefore they could either multiply the dimensionless number representing the response on an objective with a significance coefficient or they could decide beforehand to split an objective into different sub-objectives (Brauers and Ginevičius, 2009).

The Ratio System of MOORA defines internal data normalization by comparing an alternative of an objective to all values of that objective:

\footnotetext{
${ }^{1}$ Mode is the measurement with the maximum frequency if there is one. As there is only a lower limit and an upper limit the average of both is taken.
} 


$$
x_{i j}^{*}=\frac{x_{i j}}{\sqrt{\sum_{i=1}^{m} x_{i j}^{2}}},
$$

where $x_{i j}^{*}$ denotes $i$ th alternative of $j$ th objective after internal normalization. Usually these numbers belong to the interval $[-1 ; 1]$.

They are added for a maximum $(j=1,2, \ldots, g)$ or subtracted for a minimum $(j=g+1, \ldots, n)$ :

$$
y_{i}^{*}=\sum_{j=1}^{g} x_{i j}^{*}-\sum_{j=g+1}^{n} x_{i j}^{*},
$$

where $y_{i}^{*}$ denotes the internal normalized assessment of alternative $i$ with respect to all objectives. Finally, the $y_{i}^{*}$ are ranked in a descending order.

The Reference Point of MOORA is based on the ratios found in the Ratio System (9).

The reference Point can be defined in a non-subjective way as the Maximum Objective Reference Point. This approach is called realistic and non-subjective as the co-ordinates, which are selected for the reference point, are realized in one of the candidate alternatives. The alternatives A $(10 ; 100)$, B $(100 ; 20)$ and C $(50 ; 50)$ will result in the Maximal Objective Reference Point $\mathrm{R}_{m}(100 ; 100)$.

The Reference Point can also be found as an Aspiration Objective Reference or a Utopian Objective Reference Point. The co-ordinates $q_{i}$ of an Aspiration Objective Vector are formed as: $q_{j} \leqslant r_{j}$; with $\left(r_{j}-q_{j}\right)$ being a subjective element.

The Aspiration Objective Vector moderates the aspirations by choosing smaller coordinates than in the maximal objective vector. Indeed stakeholders may be more moderate in their expectations.

On the contrary, the Utopian Objective Vector gives higher values to the co-ordinates of the reference point than the maximal objective vector. Even more, a Utopian Objective Reference Point can be considered at a very large distance, rather as an ideal point not to be reached in reality. A desirable reference point as in the Utopian Objective method is then understandable for Performance Management, such as for student evaluation or for any performance in the private or public sector (Brauers, 2004). Alternatives striving only for a maximum and not for a minimum are then logical consequences of this application of the Utopian Objective Reference Point ${ }^{2}$.

The Maximal Objective Vector is self-evident, if the alternatives are well defined, as for projects in Project Analysis and Project Planning. Some call this realism only a Satisficing Result or Bounded Rationality as it seems that the stakeholders are completely satisfied if this realistic reference point is reached (Wierzbicki, 1982; Ahituv and Spector, 1990). Therefore, the Utopian Objective Vector, more than the Maximal Objective or the Aspiration Objective Vector, offers a better response to the idea of Multi-Objective Optimization.

\footnotetext{
${ }^{2}$ Nevertheless a filter can be placed beforehand, e.g., only non-smokers are allowed.
} 
The Min-Max Metric of Tchebycheff takes care of the final ranking in an ascending order:

$$
\min _{i}\left(\max _{j}\left|r_{j}-x_{i j}^{*}\right|\right)
$$

\section{The Full Multiplicative Form and MULTIMOORA}

Brauers and Zavadskas (2010a) proposed MOORA to be updated by the Full Multiplicative Form. The choice of a Utopian Objective Reference Point for Performance Management embodies only maximization of the full multiplicative utility function.

Overall utility of the $i$ t alternative can be expressed as a dimensionless number:

$$
U_{i}=\prod_{j=1}^{n} x_{i j}
$$

where $U_{i}$ denotes the product of objectives of the $i$ th alternative to be maximized with $i=1,2, \ldots, m$.

MULTIMOORA summarizes MOORA (i.e., Ratio System and Reference Point) and the Full Multiplicative Form. Ameliorated Nominal Group and Delphi techniques can be used to reduce remaining subjectivity (Brauers and Zavadskas, 2010a).

\section{The Fuzzy MULTIMOORA Method for Group Decision Making}

The fuzzy MULTIMOORA was introduced by Brauers et al. (2011). However, the fuzzy method is further modified in this study. The fuzzy MULTIMOORA for group decision making (MULTIMOORA-FG) begins with decision matrices $\tilde{X}^{k}=\tilde{x}_{i j}^{k}=$ $\left(x_{i j 1}^{k}, x_{i j 2}^{k}, x_{i j 3}^{k}\right)$, where $\tilde{x}_{i j}^{k}$ denotes $i$ th alternative of the $j$ th objective evaluated by the $k$ th decision maker $(i=1,2, \ldots, m ; j=1,2, \ldots, n ;$ and $k=1,2, \ldots, K)$. Noteworthy, these variables can represent both quantitative and qualitative assessments of alternatives. Then the responses of the decision makers are aggregated by employing fuzzy weighted averaging (FWA) operator ${ }^{3}$ (Xu and Da, 2003):

$$
\tilde{x}_{i j}=\sum_{k=1}^{K} \tilde{w}_{k} \tilde{x}_{i j}^{k} / \sum_{k=1}^{K} \tilde{w}_{k}
$$

where $\tilde{w}_{k}$ is the fuzzy coefficient of significance for the $k$ th decision maker. The equal coefficients of importance may be applied when the executive committee is homogenous, namely $\tilde{w}_{k}=(1 / K, 1 / K, 1 / K)$. Hence we arrive at the fuzzy response matrix $\tilde{X}$ with $\tilde{x}_{i j}=\left(x_{i j 1}, x_{i j 2}, x_{i j 3}\right)$ being the aggregated responses of alternatives on objectives.

\footnotetext{
${ }^{3}$ More sophisticated aggregation operators might be applied, for instance the OWA operator (Yager, 1988) and its extensions (Merigo and Casanovas, 2011; Merigo and Wei, 2011; Merigo and Gil-Laufente, 2009; Wang and Parkan, 2007; Chen and Chen, 2003).
} 


\subsection{The Fuzzy Ratio System}

The Ratio System defines internal normalization of the fuzzy numbers $\tilde{x}_{i j}$ resulting in matrix of dimensionless numbers. It is performed by comparing appropriate values of fuzzy numbers (Liu and Liu, 2010):

$$
\begin{aligned}
& \tilde{x}_{i j}^{*}=\left(x_{i j 1}^{*}, x_{i j 2}^{*}, x_{i j 3}^{*}\right) \\
& =\left\{\begin{array}{l}
x_{i j 1}^{*}=x_{i j 1} / \sqrt{\sum_{i=1}^{m}\left[\left(x_{i j 1}\right)^{2}+\left(x_{i j 2}\right)^{2}+\left(x_{i j 3}\right)^{2}\right]}, \\
x_{i j 2}^{*}=x_{i j 2} / \sqrt{\sum_{i=1}^{m}\left[\left(x_{i j 1}\right)^{2}+\left(x_{i j 2}\right)^{2}+\left(x_{i j 3}\right)^{2}\right]}, \\
x_{i j 3}^{*}=x_{i j 3} / \sqrt{\sum_{i=1}^{m}\left[\left(x_{i j 1}\right)^{2}+\left(x_{i j 2}\right)^{2}+\left(x_{i j 3}\right)^{2}\right]},
\end{array} \quad \forall i, j .\right.
\end{aligned}
$$

Computation of summarizing ratios $\tilde{y}_{i}^{*}$ for each $i$ th alternative comes next. For Performance Management the $\tilde{x}_{i j}$ are only added according to (2):

$$
\tilde{y}_{i}^{*}=\sum_{j=1}^{g} \tilde{x}_{i j}^{*} .
$$

Then each ratio $\tilde{y}_{i}^{*}=\left(y_{i 1}^{*}, y_{i 2}^{*}, y_{i 3}^{*}\right)$ is de-fuzzified by applying (8):

$$
B N P_{i}=\frac{\left(y_{i 3}^{*}-y_{i 1}^{*}\right)+\left(y_{i 2}^{*}-y_{i 1}^{*}\right)}{3}+y_{i 1}^{*}
$$

where $B N P_{i}$ denotes the best non-fuzzy performance value of the $i$ th alternative. Consequently, the alternatives with higher BNP values are attributed with higher ranks.

\subsection{The Fuzzy Reference Point}

The fuzzy Reference Point approach is based on the fuzzy Ratios obtained by (14).

The Utopian Objective Reference point $\check{r}$ is defined, in the application under consideration, as $(1,1,1)$. Performance Management does not allow that objectives should be minimized.

Every element of the ratio matrix is recalculated and final rank is given according to deviation from the reference point (6) and the Min-Max Metric of Tchebycheff:

$$
\min _{i}\left(\max _{j} d\left(\tilde{r}_{j}, \tilde{x}_{i j}^{*}\right)\right)
$$

Finally the candidates are ranked in an ascending order. 


\subsection{The Fuzzy Full Multiplicative Form}

Overall utility of the $i$ th alternative can be expressed as dimensionless number by employing (5):

$$
\tilde{U}_{i}^{\prime}=\tilde{A}_{i}=\left(A_{i 1}, A_{i 2}, A_{i 3}\right)=\prod_{j=1}^{g} \tilde{x}_{i j} .
$$

Formula (4) is applied when computing these variables. Since overall utility $\tilde{U}_{i}^{\prime}$ is a fuzzy number, (8) has to be used to rank the alternatives namely with the higher the BNP, the higher the rank of a certain alternative.

MULTIMOORA-FG summarizes fuzzy MOORA (i.e., fuzzy Ratio System and fuzzy Reference Point) and the fuzzy Full Multiplicative Form as described by the dominance theory (Brauers and Zavadskas, 2011a). The MULTIMOORA-FG is quite an effective tool for assessing sustainability of various phenomena resulting in unbiased ranking of alternatives.

\section{Personnel Selection: An Assumed Example}

Group decision-making according to MULTIMOORA-FG is applied for a personnel selection problem. The enterprise has formed an executive committee consisting of four decision makers $\left(\mathrm{DM}_{1}, \mathrm{DM}_{2}, \mathrm{DM}_{3}, \mathrm{DM}_{4}\right)$. The committee has to choose the best candidate for a vacancy from four participants $\left(\mathrm{A}_{1}, \mathrm{~A}_{2}, \mathrm{~A}_{3}, \mathrm{~A}_{4}\right)$. The committee has decided to consider eight objectives to be fulfilled as much as possible: (1) creativity, innovation $\left(\mathrm{C}_{1}\right)$; (2) leadership $\left(\mathrm{C}_{2}\right)$; (3) strategic planning $\left(\mathrm{C}_{3}\right)$; (4) communication skills $\left(\mathrm{C}_{4}\right)$; (5) team management $\left(\mathrm{C}_{5}\right)$; (6) emotional steadiness $\left(\mathrm{C}_{6}\right)$; (7) educational background $\left(\mathrm{C}_{7}\right)$ and (8) professional experience $\left(\mathrm{C}_{8}\right)$. More specifically, these objectives are expressed in linguistic variables belonging to a seven-point scale (Table 1). A scale from 1 to seven is considered as a maximum for the human brain (Miller, 1965).

Table 1

Linguistic term set for qualitative evaluation

\begin{tabular}{ll}
\hline Linguistic term & Fuzzy number \\
\hline Very low (VL) & $(0,0,0.16)$ \\
Low (L) & $(0,0.16,0.34)$ \\
Medium low (ML) & $(0.16,0.34,0.5)$ \\
Moderate (M) & $(0.34,0.5,0.66)$ \\
Medium high (MH) & $(0.5,0.66,0.84)$ \\
High (H) & $(0.66,0.84,1)$ \\
Very high (VH) & $(0.84,1,1)$ \\
Ideal (UORP) & $(1,1,1)$ \\
\hline
\end{tabular}


Table 2

Decision matrix of the four experts

\begin{tabular}{llllllllll}
\hline & & $\mathrm{C}_{1}$ & $\mathrm{C}_{2}$ & $\mathrm{C}_{3}$ & $\mathrm{C}_{4}$ & $\mathrm{C}_{5}$ & $\mathrm{C}_{6}$ & $\mathrm{C}_{7}$ & $\mathrm{C}_{8}$ \\
\hline $\mathrm{DM}_{1}$ & $\mathrm{~A}_{1}$ & $\mathrm{H}$ & $\mathrm{ML}$ & $\mathrm{VH}$ & $\mathrm{H}$ & $\mathrm{MH}$ & $\mathrm{VH}$ & $\mathrm{VH}$ & $\mathrm{H}$ \\
& $\mathrm{A}_{2}$ & $\mathrm{M}$ & $\mathrm{H}$ & $\mathrm{M}$ & $\mathrm{MH}$ & $\mathrm{H}$ & $\mathrm{M}$ & $\mathrm{VH}$ & $\mathrm{VH}$ \\
& $\mathrm{A}_{3}$ & $\mathrm{M}$ & $\mathrm{VH}$ & $\mathrm{L}$ & $\mathrm{L}$ & $\mathrm{VH}$ & $\mathrm{MH}$ & $\mathrm{H}$ & $\mathrm{VH}$ \\
& $\mathrm{A}_{4}$ & $\mathrm{VH}$ & $\mathrm{L}$ & $\mathrm{H}$ & $\mathrm{ML}$ & $\mathrm{VH}$ & $\mathrm{ML}$ & $\mathrm{ML}$ & $\mathrm{M}$ \\
$\mathrm{DM}_{2}$ & $\mathrm{~A}_{1}$ & $\mathrm{VH}$ & $\mathrm{L}$ & $\mathrm{H}$ & $\mathrm{VH}$ & $\mathrm{H}$ & $\mathrm{H}$ & $\mathrm{H}$ & $\mathrm{MH}$ \\
& $\mathrm{A}_{2}$ & $\mathrm{M}$ & $\mathrm{VH}$ & $\mathrm{H}$ & $\mathrm{VH}$ & $\mathrm{VH}$ & $\mathrm{H}$ & $\mathrm{MH}$ & $\mathrm{MH}$ \\
& $\mathrm{A}_{3}$ & $\mathrm{H}$ & $\mathrm{H}$ & $\mathrm{MH}$ & $\mathrm{M}$ & $\mathrm{H}$ & $\mathrm{MH}$ & $\mathrm{M}$ & $\mathrm{H}$ \\
& $\mathrm{A}_{4}$ & $\mathrm{M}$ & $\mathrm{ML}$ & $\mathrm{MH}$ & $\mathrm{H}$ & $\mathrm{MH}$ & $\mathrm{ML}$ & $\mathrm{M}$ & $\mathrm{M}$ \\
$\mathrm{DM}_{3}$ & $\mathrm{~A}_{1}$ & $\mathrm{M}$ & $\mathrm{MH}$ & $\mathrm{H}$ & $\mathrm{MH}$ & $\mathrm{MH}$ & $\mathrm{H}$ & $\mathrm{H}$ & $\mathrm{MH}$ \\
& $\mathrm{A}_{2}$ & $\mathrm{M}$ & $\mathrm{H}$ & $\mathrm{VH}$ & $\mathrm{H}$ & $\mathrm{M}$ & $\mathrm{MH}$ & $\mathrm{VH}$ & $\mathrm{H}$ \\
& $\mathrm{A}_{3}$ & $\mathrm{H}$ & $\mathrm{H}$ & $\mathrm{MH}$ & $\mathrm{MH}$ & $\mathrm{H}$ & $\mathrm{MH}$ & $\mathrm{M}$ & $\mathrm{ML}$ \\
& $\mathrm{A}_{4}$ & $\mathrm{H}$ & $\mathrm{H}$ & $\mathrm{ML}$ & $\mathrm{M}$ & $\mathrm{H}$ & $\mathrm{L}$ & $\mathrm{M}$ & $\mathrm{M}$ \\
& $\mathrm{A}_{1}$ & $\mathrm{H}$ & $\mathrm{MH}$ & $\mathrm{VH}$ & $\mathrm{M}$ & $\mathrm{M}$ & $\mathrm{MH}$ & $\mathrm{MH}$ & $\mathrm{MH}$ \\
$\mathrm{DM}_{4}$ & $\mathrm{~A}_{2}$ & $\mathrm{H}$ & $\mathrm{H}$ & $\mathrm{MH}$ & $\mathrm{VH}$ & $\mathrm{VH}$ & $\mathrm{H}$ & $\mathrm{H}$ & $\mathrm{MH}$ \\
& $\mathrm{A}_{3}$ & $\mathrm{VH}$ & $\mathrm{VH}$ & $\mathrm{H}$ & $\mathrm{VH}$ & $\mathrm{MH}$ & $\mathrm{H}$ & $\mathrm{M}$ & $\mathrm{VH}$ \\
& $\mathrm{A}_{4}$ & $\mathrm{VH}$ & $\mathrm{VH}$ & $\mathrm{M}$ & $\mathrm{ML}$ & $\mathrm{H}$ & $\mathrm{H}$ & $\mathrm{ML}$ & $\mathrm{ML}$ \\
\hline
\end{tabular}

As said above the Utopian Objective Reference Point is preferred for Performance Management ahead of the other definitions of a reference point. Therefore a Utopian Objective Reference Point $(1,1,1$, will be added as UORP to strive for. Table 1 brings the fuzzy numbers translations of the linguistic variables.

Each of the decision makers evaluated every candidate according to the eight attributes (Table 2).

Table A1 in Annex A presents the results of translation of these ratings into fuzzy numbers as described in Table 1. The FWA operator (13) with uniform coefficients of significance, namely $\tilde{w}_{k}=(1 / 4,1 / 4,1 / 4)$ for all $k$, was applied. Nevertheless it is always possible that a decision maker, for instance the head of the personnel department, is more important for this application than the other ones. At that moment his significance coefficient is for instance doubled.

Table A2 of Annex A calculates the ratios by aggregation and by applying (14).

1. The Fuzzy Ratio System. The $\tilde{x}_{i j}$ are added to come to sums of ratios $\tilde{y}_{i}^{*}$ for each $i$ th alternative (15). Each ratio $\tilde{y}_{i}^{*}=\left(y_{i 1}^{*}, y_{i 2}^{*}, y_{i 3}^{*}\right)$ is de-fuzzified by (16).

The candidates were ranked according to the fuzzy Ratio System in a descending order (Annex A Table A5). The second candidate $\left(\mathrm{A}_{2}\right)$ was considered the best one and the fourth candidate $\left(\mathrm{A}_{4}\right)$ the worst one.

2. Reference Point Method. A reference point was defined as the Utopian Objective Reference Point $(1,1,1)$. We proceeded with calculations of deviations of each alternative from this reference point by applying (17). The candidates were ranked 
Table 3

Ranking of the candidates according to MULTIMOORA-FG

\begin{tabular}{lllll}
\hline & $\begin{array}{l}\text { The fuzzy } \\
\text { Ratio System }\end{array}$ & $\begin{array}{l}\text { The fuzzy } \\
\text { Reference Point }\end{array}$ & $\begin{array}{l}\text { The fuzzy Full } \\
\text { Multiplicative Form }\end{array}$ & MULTIMOORA-FG \\
\hline $\mathrm{A}_{1}$ & 2 & 3 & 2 & $\mathbf{2}$ \\
$\mathrm{A}_{2}$ & 1 & 2 & 1 & $\mathbf{1}$ \\
$\mathrm{A}_{3}$ & 3 & 1 & 3 & $\mathbf{3}$ \\
$\mathrm{A}_{4}$ & 4 & 4 & 4 & $\mathbf{4}$ \\
\hline
\end{tabular}

according to the fuzzy Reference Point in an ascending order (Annex A Table A4). In this case, the third candidate was the most preferred.

3. Full Multiplicative Form. The Full Multiplicative Form (18) suggested the second candidate being the best one (Annex A Table A5).

4. MULTIMOORA-FG. The theory of dominance (Brauers and Zavadskas 2011a) was applied when summarizing the ranks provided by different parts of MULTIMOORA-FG.

The three methods of MULTIMOORA were assumed to have the same importance. It was already noticed that one decision maker could be more important than the other ones but this is not the case with the three methods of MULTIMOORA. These three methods represent all existing methods with dimensionless measures in multi-objective optimization and consequently all the three have the same significance of importance.

As shown in Table 3, the second candidate $\mathrm{A}_{2}$ should be employed before candidate $\mathrm{A}_{1}$ who dominates candidate $\mathrm{A}_{3}$, on its turn dominating candidate $\mathrm{A}_{4}$.

The numerical example exhibited possibilities for improvement of human resources management by applying MULTIMOORA-FG. However, further studies, empirical and not simulated, might be useful when based on real fieldwork.

\section{Conclusion}

This study extended the MULTIMOORA method itself composed of the Ratio System, the Reference Point and the Full Multiplicative Form methods to a MULTIMOORA-FG method. This proposed MULTIMOORA-FG method is suitable for tackling uncertain information, for it allows fuzzy inputs (e.g., linguistic variables identifying expert assessments), which, in turn, reduces information losses throughout computation.

Moreover, the new MULTIMOORA-FG method is extended to cope with group decision-making. A personnel selection problem illustrates the group decision-making procedure according to MULTIMOORA-FG. In our example, an executive committee consisting of four decision makers was to choose the best candidate from four participants. The committee has decided to consider eight qualitative objectives. More specifically, these objectives were expressed in linguistic variables belonging to a seven-point scale. 
The theory of dominance was applied when summarizing the ranks provided by different parts of MULTIMOORA-FG, namely the fuzzy Ratio System, the fuzzy Reference Point, and the fuzzy Full Multiplicative Form. Hence, the MULTIMOORA-FG might be suitable when making business decisions which require quantitative as well as qualitative inputs. However, further studies might be useful for extending the method if it would be based on empirical data.

\section{References}

Ahituv, N., Spector, Y. (1990). Evaluating Information under two Criteria: Expected Payoff and Risk. Working paper No. 70/90. I.I.B.R., Tel Aviv University, Israel, 5.

Belton, V., Stewart, T.J. (2002). Multiple criteria decision analysis: an integrated approach. Boston, Kluwer Academic.

Brauers, W.K. (2004). Optimization Methods for a Stakeholder Society, a Revolution in Economic Thinking by Multi-Objective Optimization. Boston, Kluwer Academic.

Brauers, W.K. (2007). What is meant by normalization in decision making? International Journal of Management and Decision Making, 8(5/6), 445-460.

Brauers, W.K.M., Ginevičius, R. (2009). Robustness in regional development studies: The case of Lithuania. Journal of Business Economics and Management, 10(2), 121-140.

Brauers, W.K.M., Ginevičius, R. (2010). The economy of the Belgian regions tested with MULTIMOORA. Journal of Business Economics and Management, 11(2), 173-209.

Brauers, W.K.M., Zavadskas, E.K. (2006). The MOORA method and its application to privatization in a transition economy. Control and Cybernetics, 35(2), 445-469.

Brauers, W.K., Zavadskas, E.K. (2009). Robustness of the multi-objective MOORA method with a test for the facilities sector. Technological and Economic Development of Economy, 15(2), 352-375.

Brauers, W.K.M., Zavadskas, E.K. (2010a). Project management by MULTIMOORA as an instrument for transition economies. Technological and Economic Development of Economy, 16(1), 5-24.

Brauers, W.K.M., Zavadskas, E.K. (2010b). Robustness in the MULTIMOORA model: the example of Tanzania. Transformations in Business \& Economics, 9(3), 67-83.

Brauers, W.K.M., Zavadskas, E.K. (2011a). MULTIMOORA optimization used to decide on a bank loan to buy property. Technological and Economic Development of Economy, 17(1), 174-188.

Brauers, W.K.M., Zavadskas, E.K. (2011b). From a centrally planned economy to multiobjective optimization in an enlarged project management: the case of China. Economic Computation and Economic Cybernetics Studies and Research, (1), 167-188.

Brauers, W.K.M., Ginevičius, R., Zavadskas E.K., Antuchevičienė J. (2007). The European Union in a transition economy. Transformation in Business \& Economics, 6(2), 21-37.

Brauers, W.K.M., Zavadskas, E.K., Turskis, Z., Vilutienè, T. (2008a). Multi-objective contractor's ranking by applying the MOORA method. Journal of Business Economics and Management, 9(4), 245-255.

Brauers, W.K.M., Zavadskas, E.K., Peldschus, F., Turskis, Z. (2008b). Multi-objective decision-making for road design. Transport, 23(3), 183-193.

Brauers, W.K. M., Baležentis, A., Baležentis, T. (2011). MULTIMOORA for the EU Member States updated with fuzzy number theory. Technological and Economic Development of Economy, 17(2), 259-290.

Chakraborty, S. (2011). Applications of the MOORA method for decision making in manufacturing environment. The International Journal of Advanced Manufacturing Technology, 54, 1155-1166.

Chen, C.T. (2000). Extensions of the TOPSIS for group decision-making under fuzzy environment. Fuzzy Sets and Systems, 114, 1-9.

Chen, S.J., Chen, S.M. (2003). A new method for handling multicriteria fuzzy decision-making problems using FN-IOWA operators. Cybernetics and Systems: An International Journal, 34, 109-137.

Chou, S.Y., Chang, Y.H., Shen, C.Y. (2008). A fuzzy simple additive weighting system under group decisionmaking for facility location selection with objective/subjective attributes. European Journal of Operational Research, 189, 132-145. 
Dursun, M., Karsak, E. (2010). A fuzzy MCDM approach for personnel selection. Expert Systems with Applications, 37, 4324-4330.

Kahraman, C. (2008). Multi-criteria decision making methods and fuzzy sets. In: Kahraman, C. (Ed.) Fuzzy Multi-Criteria Decision Making. Springer, Berlin.

Kahraman, C., Kaya, İ. (2010). Investment analyses using fuzzy probability concept. Technological and Economic Development of Economy, 16(1), 43-57.

Kaya, T., Kahraman, C. (2011). A fuzzy approach to e-banking website quality assessment based on an integrated AHP-ELECTRE method. Technological and Economic Development of Economy, 17(2), 313-334.

Kalibatas, D., Turskis, Z. (2008). Multicriteria evaluation of inner climate by using MOORA method. Information Technology and Control, 37(1), 79-83.

Kelemenis, A., Askounis, D. (2010). A new TOPSIS-based multi-criteria approach to personnel selection. Expert Systems with Applications, 37, 4999-5008.

Kelemenis, A., Ergazakis, K., Askounis, D. (2011). Support managers' selection using an extension of fuzzy TOPSIS. Expert Systems with Applications, 38, 2774-2782.

Keufmann, A., Gupta, M.M. (1991). Introduction to Fuzzy Arithmetic: Theory and Application. Van NostrandReinhold, New York.

Kracka, M., Brauers, W.K.M., Zavadskas, E.K. (2010). Ranking heating losses in a building by applying the MULTIMOORA. Inžineriné ekonomika - Engineering Economics, 21(4), 352-359.

Liang, G.S. 1999. Fuzzy MCDM based on ideal and anti-ideal concepts. European Journal of Operational Research, 112, 682-691.

Liang, G.S., Ding, J.F. (2003). Fuzzy MCDM based on the concept of $\alpha$-cut. Journal of Multi-Criteria Decision Analysis, 12(6), 299-310.

Liu, P. (2009). A novel method for hybrid multiple attribute decision making. Knowledge-Based Systems, 22(5), 388-391. doi:10.1016/j.knosys.2009.02.001

Liu, W., Liu, P. (2010). Hybrid multiple attribute decision making method based on relative approach degree of grey relation projection. African Journal of Business Management, 4(17), 3716-3724.

Loken, E. (2007). Use of multicriteria decision analysis methods for energy planning problems. Renewable and Sustainable Energy Reviews, 11, 1584-1595.

MacCrimmon, K.R. (1968). Decision Making Among Multiple Attribute Alternatives: A Survey and Consolidated Approach. RAND Memorandum, RM-4823-ARPA. The RAND Corporation, Santa Monica.

Merigo, J.M., Casanovas, M. (2011). Induced and uncertain heavy OWA operators. Computers \& Industrial Engineering, 60, 106-116.

Merigo, J.M., Gil-Laufente, A. (2009). The induced generalized OWA operator. Information Sciences, 179, 729-741.

Merigo, J.M., Gil-Laufente, A.M. (2011). OWA operators in human resource management. Economic Computation and Economic Cybernetics Studies and Research, 45(2), 153-168.

Merigo, J.M., Wei, G.W. (2011) Probabilistic aggregation operators and their application in uncertain multiperson decision-making. Technological and Economic Development of Economy, 17(2), 335-351.

Miller, G.A. (1965). The magical number seven plus or minus two: some limits on our capacity for processing information, Psychological Review, 63, 81-97.

Peldschus, F. (2009). The analysis of the quality of the results obtained with the methods of multi-criteria decisions. Technological and Economic Development of Economy, 15(4), 580-592.

Peldschus, F., Zavadskas, E.K. (2005). Fuzzy matrix games multi-criteria model for decision-making in engineering. Informatica, 16(1), 107-120.

Roy, B. (1996). Multicriteria Methodology for Decision Aiding. Kluwer Academic Dordrecht.

Triantaphyllou, E. (2000). Multi-Criteria Decision Making Methods: a Comparative Study. Kluwer Academic Dordrecht.

Torlak, G., Sevkli, M., Sanal, M., Zaim, S. (2011). Analyzing business competition by using fuzzy TOPSIS method: an example of Turkish domestic airline industry. Expert Systems with Applications, 38(4), 33969406. doi:10.1016/j.eswa.2010.08.125

Wang, Y.M., Parkan, C. (2007). A preemptive goal programming method for aggregating OWA operator weights in group decision making. Information Sciences, 177, 1867-1877.

Wierzbicki, A.P. (1982). A mathematical basis for satisficing decision making, Mathematical Modelling, 3(5), 391-405. 
Xu, Z.S., Da, Q.L. (2003). An overview of operators for aggregating information. International Journal of Intelligent Systems, 18, 953-969.

Yager, R.R. (1988). On ordered weighted averaging aggregation operators in multi-criteria decision making. IEEE Transactions on Systems, Man and Cybernetics, 18, 183-190.

Yao, J.S., Wu, K. (2000). Ranking fuzzy numbers based on decomposition principle and signed distance. Fuzzy Sets and Systems, 116, 275-288.

Zadeh, L.A. (1965). Fuzzy sets. Information and Control, 8(1), 338-353.

Zadeh, L.A. (1975a). The concept of a linguistic variable and its application to approximate reasoning - I. Information Sciences, 8(3), 199-249.

Zadeh, L.A. (1975b). The concept of a linguistic variable and its application to approximate reasoning - II. Information Sciences, 8(4), 301-357.

Zadeh, L.A. (1975c). The concept of a linguistic variable and its application to approximate reasoning - III. Information Sciences, 9(1), 43-80.

Zavadskas, E.K., Antucheviciene, J. (2006). Development of an indicator model and ranking of sustainable revitalization alternatives of derelict property: a Lithuanian case study. Sustainable Development, 14(5), 287-299.

Zavadskas, E.K., Antucheviciene, J. (2007). Multiple criteria evaluation of rural building's regeneration alternatives. Building and Environment, 42(1), 436-451.

Zavadskas, E.K., Turskis, Z. (2011). Multiple criteria decision making (MCDM) methods in economics: an overview. Technological and Economic Development of Economy, 17(2), 397-427.

Zavadskas, E.K., Turskis, Z., Tamošaitiene, J., Marina, V. (2008). Multicriteria selection of project managers by applying grey criteria. Technological and Economic Development of Economy, 14(4), 462-477.

Zavadskas, E.K., Turskis, Z., Ustinovichius, L., Shevchenko, G. (2010). Attributes weights determining peculiarities in multiple attribute decision making methods. Inzinerine Ekonomika-Engineering Economics, $21(1), 32-43$.

Zhang, X., Liu, P. (2010). Method for aggregating triangular fuzzy intuitionistic fuzzy information and its application to decision making. Technological and Economic Development of Economy, 16(2), 280-290.

Zhang, S.F., Liu, S.Y. (2011). A GRA-based intuitionistic fuzzy multi-criteria group decision making method for personnel selection. Expert Systems with Applications. doi,10.1016/j.eswa.2011.03.012

Zhao, R., Govind, R. (1991). Algebraic characteristics of extended fuzzy numbers, Information Science, 54(1), 103-130. 


\section{Annex A. Group Decision Making According to MULTIMOORA-FG}

Table A1

The ratings of the four decision-makers expressed in triangular fuzzy numbers

\begin{tabular}{|c|c|c|c|c|c|c|c|c|c|}
\hline & & $\mathrm{C}_{1}$ & $\mathrm{C}_{2}$ & $\mathrm{C}_{3}$ & $\mathrm{C}_{4}$ & $\mathrm{C}_{5}$ & $\mathrm{C}_{6}$ & $\mathrm{C}_{7}$ & $\mathrm{C}_{8}$ \\
\hline \multirow[t]{4}{*}{$\mathrm{DM}_{1}$} & $\mathrm{~A}_{1}$ & $(0.66,0.84,1)$ & $(0.16,0.34,0.5)$ & $(0.84,1,1)$ & $(0.66,0.84,1)$ & $(0.5,0.66,0.84)$ & $(0.84,1,1)$ & $(0.84,1,1)$ & $(0.66,0.84,1)$ \\
\hline & $\mathrm{A}_{2}$ & $(0.34,0.5,0.66)$ & $(0.66,0.84,1)$ & $(0.34,0.5,0.66)$ & $(0.5,0.66,0.84)$ & $(0.66,0.84,1)$ & $(0.34,0.5,0.66)$ & $(0.84,1,1)$ & $(0.84,1,1)$ \\
\hline & $\mathrm{A}_{3}$ & $(0.34,0.5,0.66)$ & $(0.84,1,1)$ & $(, 0.16,0.34)$ & $(, 0.16,0.34)$ & $(0.84,1,1)$ & $(0.5,0.66,0.84)$ & $(0.66,0.84,1)$ & $(0.84,1,1)$ \\
\hline & $\mathrm{A}_{4}$ & $(0.84,1,1)$ & $(, 0.16,0.34)$ & $(0.66,0.84,1)$ & $(0.16,0.34,0.5)$ & $(0.84,1,1)$ & $(0.16,0.34,0.5)$ & $(0.16,0.34,0.5)$ & $(0.34,0.5,0.66)$ \\
\hline \multirow[t]{4}{*}{$\mathrm{DM}_{2}$} & $\mathrm{~A}_{1}$ & $(0.84,1,1)$ & $(, 0.16,0.34)$ & $(0.66,0.84,1)$ & $(0.84,1,1)$ & $(0.66,0.84,1)$ & $(0.66,0.84,1)$ & $(0.66,0.84,1)$ & $(0.5,0.66,0.84)$ \\
\hline & $\mathrm{A}_{2}$ & $(0.34,0.5,0.66)$ & $(0.84,1,1)$ & $(0.66,0.84,1)$ & $(0.84,1,1)$ & $(0.84,1,1)$ & $(0.66,0.84,1)$ & $(0.5,0.66,0.84)$ & $(0.5,0.66,0.84)$ \\
\hline & $\mathrm{A}_{3}$ & $(0.66,0.84,1)$ & $(0.66,0.84,1)$ & $(0.5,0.66,0.84)$ & $(0.34,0.5,0.66)$ & $(0.66,0.84,1)$ & $(0.5,0.66,0.84)$ & $(0.34,0.5,0.66)$ & $(0.66,0.84,1)$ \\
\hline & $\mathrm{A}_{4}$ & $(0.34,0.5,0.66)$ & $(0.16,0.34,0.5)$ & $(0.5,0.66,0.84)$ & $(0.66,0.84,1)$ & $(0.5,0.66,0.84)$ & $(0.16,0.34,0.5)$ & $(0.34,0.5,0.66)$ & $(0.34,0.5,0.66)$ \\
\hline \multirow[t]{4}{*}{$\mathrm{DM}_{3}$} & $\mathrm{~A}_{1}$ & $(0.34,0.5,0.66)$ & $(0.5,0.66,0.84)$ & $(0.66,0.84,1)$ & $(0.5,0.66,0.84)$ & $(0.5,0.66,0.84)$ & $(0.66,0.84,1)$ & $(0.66,0.84,1)$ & $(0.5,0.66,0.84)$ \\
\hline & $\mathrm{A}_{2}$ & $(0.34,0.5,0.66)$ & $(0.66,0.84,1)$ & $(0.84,1,1)$ & $(0.66,0.84,1)$ & $(0.34,0.5,0.66)$ & $(0.5,0.66,0.84)$ & $(0.84,1,1)$ & $(0.66,0.84,1)$ \\
\hline & $\mathrm{A}_{3}$ & $(0.66,0.84,1)$ & $(0.66,0.84,1)$ & $(0.5,0.66,0.84)$ & $(0.5,0.66,0.84)$ & $(0.66,0.84,1)$ & $(0.5,0.66,0.84)$ & $(0.34,0.5,0.66)$ & $(0.16,0.34,0.5)$ \\
\hline & $\mathrm{A}_{4}$ & $(0.66,0.84,1)$ & $(0.66,0.84,1)$ & $(0.16,0.34,0.5)$ & $(0.34,0.5,0.66)$ & $(0.66,0.84,1)$ & $(, 0.16,0.34)$ & $(0.34,0.5,0.66)$ & $(0.34,0.5,0.66)$ \\
\hline \multirow[t]{4}{*}{$\mathrm{DM}_{4}$} & $\mathrm{~A}_{1}$ & $(0.66,0.84,1)$ & $(0.5,0.66,0.84)$ & $(0.84,1,1)$ & $(0.34,0.5,0.66)$ & $(0.34,0.5,0.66)$ & $(0.5,0.66,0.84)$ & $(0.5,0.66,0.84)$ & $(0.5,0.66,0.84)$ \\
\hline & $\mathrm{A}_{2}$ & $(0.66,0.84,1)$ & $(0.66,0.84,1)$ & $(0.5,0.66,0.84)$ & $(0.84,1,1)$ & $(0.84,1,1)$ & $(0.66,0.84,1)$ & $(0.66,0.84,1)$ & $(0.5,0.66,0.84)$ \\
\hline & $\mathrm{A}_{3}$ & $(0.84,1,1)$ & $(0.84,1,1)$ & $(0.66,0.84,1)$ & $(0.84,1,1)$ & $(0.5,0.66,0.84)$ & $(0.66,0.84,1)$ & $(0.34,0.5,0.66)$ & $(0.84,1,1)$ \\
\hline & $\mathrm{A}_{4}$ & $(0.84,1,1)$ & $(0.84,1,1)$ & $(0.34,0.5,0.66)$ & $(0.16,0.34,0.5)$ & $(0.66,0.84,1)$ & $(0.66,0.84,1)$ & $(0.16,0.34,0.5)$ & $(0.16,0.34,0.5)$ \\
\hline
\end{tabular}


Table A2

Ratios for each alternative (candidate)

\begin{tabular}{lllllllll}
\hline & $\mathrm{C}_{1}$ & $\mathrm{C}_{2}$ & $\mathrm{C}_{3}$ & $\mathrm{C}_{4}$ & $\mathrm{C}_{5}$ & $\mathrm{C}_{6}$ & $\mathrm{C}_{7}$ & $\mathrm{C}_{8}$ \\
\hline $\mathrm{A}_{1}$ & $(0.63,0.8,0.92)$ & $(0.29,0.46,0.63)$ & $(0.75,0.92,1)$ & $(0.59,0.75,0.88)$ & $(0.5,0.67,0.84)$ & $(0.67,0.84,0.96)$ & $(0.67,0.84,0.96)$ & $(0.54,0.705,0.88)$ \\
$\mathrm{A}_{2}$ & $(0.42,0.59,0.75)$ & $(0.71,0.88,1)$ & $(0.59,0.75,0.88)$ & $(0.71,0.88,0.96)$ & $(0.67,0.84,0.92)$ & $(0.54,0.71,0.88)$ & $(0.71,0.88,0.96)$ & $(0.625,0.79,0.92)$ \\
$\mathrm{A}_{3}$ & $(0.63,0.8,0.92)$ & $(0.75,0.92,1)$ & $(0.42,0.58,0.76)$ & $(0.42,0.58,0.71)$ & $(0.67,0.84,0.96)$ & $(0.54,0.71,0.88)$ & $(0.42,0.59,0.75)$ & $(0.625,0.795,0.875)$ \\
$\mathrm{A}_{4}$ & $(0.67,0.84,0.92)$ & $(0.42,0.59,0.71)$ & $(0.42,0.59,0.75)$ & $(0.33,0.51,0.67)$ & $(0.67,0.84,0.96)$ & $(0.25,0.42,0.59)$ & $(0.25,0.42,0.58)$ & $(0.295,0.46,0.62)$ \\
\hline
\end{tabular}

Table A3

Normalized aggregated ratings for each alternative (candidate) and the Utopian Objective Reference Point

\begin{tabular}{lllllllll}
\hline & $\mathrm{C}_{1}$ & $\mathrm{C}_{2}$ & $\mathrm{C}_{3}$ & $\mathrm{C}_{4}$ & $\mathrm{C}_{5}$ & $\mathrm{C}_{6}$ & $\mathrm{C}_{7}$ & $\mathrm{C}_{8}$ \\
\hline $\mathrm{A}_{1}$ & $(0.24,0.31,0.35)$ & $(0.11,0.18,0.25)$ & $(0.3,0.37,0.4)$ & $(0.25,0.31,0.37)$ & $(0.18,0.24,0.31)$ & $(0.28,0.35,0.4)$ & $(0.27,0.34,0.4)$ & $(0.22,0.29,0.36)$ \\
$\mathrm{A}_{2}$ & $(0.16,0.22,0.29)$ & $(0.28,0.35,0.4)$ & $(0.23,0.3,0.35)$ & $(0.3,0.37,0.4)$ & $(0.24,0.31,0.33)$ & $(0.22,0.3,0.36)$ & $(0.29,0.36,0.4)$ & $(0.26,0.33,0.38)$ \\
$\mathrm{A}_{3}$ & $(0.24,0.31,0.35)$ & $(0.3,0.36,0.4)$ & $(0.17,0.23,0.3)$ & $(0.18,0.24,0.3)$ & $(0.24,0.31,0.35)$ & $(0.22,0.29,0.37)$ & $(0.17,0.24,0.31)$ & $(0.26,0.33,0.36)$ \\
$\mathrm{A}_{4}$ & $(0.26,0.32,0.35)$ & $(0.16,0.23,0.28)$ & $(0.17,0.23,0.3)$ & $(0.14,0.21,0.28)$ & $(0.24,0.31,0.35)$ & $(0.1,0.17,0.24)$ & $(0.1,0.17,0.24)$ & $(0.12,0.19,0.26)$ \\
$\tilde{r}$ & $(1,1,1)$ & $(1,1,1)$ & $(1,1,1)$ & $(1,1,1)$ & $(1,1,1)$ & $(1,1,1)$ & $(1,1,1)$ & $(1,1,1)$ \\
\hline
\end{tabular}


Table A4

The fuzzy Reference Point approach

\begin{tabular}{lllllllllll}
\hline & $\mathrm{C}_{1}$ & $\mathrm{C}_{2}$ & $\mathrm{C}_{3}$ & $\mathrm{C}_{4}$ & $\mathrm{C}_{5}$ & $\mathrm{C}_{6}$ & $\mathrm{C}_{7}$ & $\mathrm{C}_{8}$ & $\underset{j}{\max d\left(\tilde{r}_{j}, \tilde{x}_{i j}^{*}\right)}$ & Rank \\
\hline $\mathrm{A}_{1}$ & 0.7025 & 0.8205 & 0.6449 & 0.6928 & 0.7581 & 0.6604 & 0.6643 & 0.7106 & 0.8205 & 3 \\
$\mathrm{~A}_{2}$ & 0.7776 & 0.6608 & 0.7066 & 0.6457 & 0.7063 & 0.7073 & 0.6522 & 0.6813 & 0.7776 & 2 \\
$\mathrm{~A}_{3}$ & 0.7025 & 0.6491 & 0.7684 & 0.7626 & 0.7019 & 0.7073 & 0.7618 & 0.6863 & 0.7684 & 1 \\
$\mathrm{~A}_{4}$ & 0.6912 & 0.7759 & 0.7683 & 0.7924 & 0.7019 & 0.8285 & 0.8303 & 0.8131 & 0.8303 & 4 \\
\hline
\end{tabular}

Table A5

The fuzzy Ratio System and the fuzzy Full Multiplicative Form

\begin{tabular}{|c|c|c|c|c|c|c|}
\hline & \multicolumn{3}{|c|}{ The fuzzy Ratio System } & \multicolumn{3}{|c|}{ The fuzzy Full Multiplicative Form } \\
\hline & $\overline{\tilde{y}_{i}^{*}}$ & $B N P_{i}$ & Rank & $\overline{\tilde{U}_{i}^{\prime}}$ & $B N P_{i}$ & Rank \\
\hline $\mathrm{A}_{1}$ & $(1.86,2.39,2.83)$ & 2.36009 & 2 & $(0.00001,0.00005,0.00022)$ & 0.000095 & 2 \\
\hline $\mathrm{A}_{2}$ & $(1.99,2.53,2.91)$ & 2.475324 & 1 & $(0.00001,0.00009,0.00029)$ & 0.000132 & 1 \\
\hline $\mathrm{A}_{3}$ & $(1.78,2.31,2.73)$ & 2.27359 & 3 & $(0.00001,0.00004,0.00018)$ & 0.000076 & 3 \\
\hline $\mathrm{A}_{4}$ & $(1.3,1.84,2.3)$ & 1.8121 & 4 & $(0,0.00001,0.00004)$ & 0.000017 & 4 \\
\hline
\end{tabular}

A. Baležentis, $\mathrm{PhD}(\mathrm{HP})$ in management and administration, is professor at the Department of Strategic Management in Mykolas Romeris University. While working at the Parliament of the Republic of Lithuania, Ministry of Agriculture, and Institute of Agrarian Economics he contributed to creation and fostering of the Lithuanian rural development policy at various levels. His scientific interests cover areas of innovatics, strategic management, sustainable development and rural development.

T. Baležentis is specialist at the Lithuanian Institute of Agrarian Economics. His working experience includes traineeship at the European Parliament and working at the Training Centre of the Ministry of Finance. His scientific interests: quantitative methods in social sciences, multi-criteria decision making, fuzzy logics, European integration processes, agricultural economics. 
W.K.M. Brauers was graduated as $\mathrm{PhD}$ in economics (University of Leuven), master of arts (in economics) of Columbia University (New York), master in economics, in management and financial sciences, in political and diplomatic sciences and bachelor in philosophy all of the University of Leuven). He is professor ordinarius at the Faculty of Applied Economics of the University of Antwerp, honorary professor at the University of Leuven, the Belgian War College, the School of Military Administrators and the Antwerp Business School. He was a research fellow in several American institutions like Rand Corporation, the Institute for the Future, the Futures Group and extraordinary advisor to the Center for Economic Studies of the University of Leuven. He was consultant in the public sector, such as the Belgian Department of National Defense, the Department of Industry in Thailand, the project for the construction of a new port in Algeria (the port of Arzew) and in the private sector such as the international seaport of Antwerp and in electrical works. He was chairman of the Board of Directors of SORCA Ltd. Brussels, management consultants for developing countries, linked to the worldwide group of ARCADIS and chairman of the Board of Directors of MARESCO Ltd. Antwerp, Marketing Consultants. At the moment he is general manager of CONSULTING, Systems Engineering Consultants. Brauers is member of many international scientific organizations. His specialization covers: optimizing techniques with different objectives, forecasting techniques, input-output techniques and public sector economics such as for national defense and for regional sub-optimization. His scientific publications consist of seventeen books and several hundreds of articles and reports.

\section{MULTIMOORA-FG: daugiatikslio sprendimu prièmimo metodas lingvistiniam pagrindimui ir jo taikymas personalo atrankoje}

\footnotetext{
Alvydas BALEŽENTIS, Tomas BALEŽENTIS, Willem K.M. BRAUERS

Šio straipsnio tikslas - pritaikyti neraiškuji MULTIMOORA metodą lingvistiniam programavimui grupiniame sprendimu prièmime. Naujasis MULTIMOORA-FG metodas sudarytas iš triju dalių: neraiškiosios santykių sistemos, neraiškiojo atskaitos taško, neraiškiosios pilnosios sandaugos formos. Minètu trijų metodu taikymas leidžia atlikti efektyvu alternatyvu ivvertinimą atsižvelgiant ị daugelị iš anksto apibrèžtu tikslų. MULTIMOORA-FG metodas leidžia apdoroti trečiojo laipsnio neraiškiuosius skaičius, kurie gali atspindèti kiekybinę ir kokybinę informacija, pavyzdžiui lingvistinius kintamuosius. Taigi naujasis metodas tinkamas lingvistiniam sprendimu pagrindimui. Šiame straipsnyje MULTIMOORA-FG pritaikytas apibendrinant skirtingų ekspertų nuomones ir taip atliekant atsparią nuokrypiams personalo atranką. Dèl personalo atrankos procese pasitaikančio neapibrěžtumo, dviprasmiškumo ir netikslumo, jame tikslinga taikyti daugiakriterinio vertinimo metodus bei šiuolaikines informacines technologijas. Konkreti personalo atrankos problema buvo panaudota kaip MULTIMOORA-FG metodo taikymo pavyzdys: įmoné sudare keturių ekspertu grupe personalo atrankai, ekspertai vertino kandidatus pagal aštuonis kriterijus. Šie kokybiniai kriterijai buvo išreikšti lingvistiniais kintamaisiais. Minètas skaitinis pavyzdys patvirtino galimybę patobulinti žmogiškujų išteklių valdymą taikant naujajị metodą MULTIMOORA-FG.
} 